\title{
Simultaneous Monitoring of Toxic Metals on White Poplar (Populus) by SWASV
}

\author{
Nelson A. F. Silva ${ }^{*, a}$, Maria I. Lopes ${ }^{b}$, Ruben A. E. Leitão ${ }^{a}$, Hugo F. A. Silva ${ }^{a}$ \\ and Manuel J. Matos ${ }^{a, c}$ \\ ${ }^{a}$ Centro de Investigação de Engenharia Química e Biotecnologia do ISEL/DEQ, \\ Av. Conselheiro Emídio Navarro, 1, 1949-014 Lisboa, Portugal \\ ${ }^{b}$ Departamento de Química e Bioquímica - FCUL, Campo Grande, Edifício C8 1749-016 Lisboa, Portugal \\ ${ }^{c}$ Instituto de Telecomunicações - IST, Torre Norte, Piso 10, Av. Rovisco Pais, 1, 1049-001 Lisboa, Portugal
}

\begin{abstract}
A técnica electroanalítica, Voltametria de Redissolução Anódica de Onda Quadrada (VRAOQ), foi utilizada na determinação simultânea de quantidades traço dos metais tóxicos $\mathrm{Pb}(\mathrm{II}), \mathrm{Cd}(\mathrm{II})$ e $\mathrm{Cu}(\mathrm{II})$ em folhas de choupo (populus), utilizadas como bio-indicador, recolhidas numa área de tráfego automóvel intenso da cidade de Lisboa. As folhas, após secagem, foram submetidas a um processo de digestão ácida por microondas. Para a aplicação desta técnica à análise das folhas foi realizado um estudo de optimização dos vários parâmetros voltamétricos. $\mathrm{O}$ eletrodo de trabalho consistiu num filme de mercúrio depositado numa superfície de carbono vítreo. O sistema $\mathrm{Ag} / \mathrm{AgCl}$ foi utilizado como referência e um fio de Platina como eletrodo auxiliar. Concentrações médias (em $\mathrm{mg}$ de metal/kg de matéria seca - folhas) de 2,6, 0,18 e 5,0 foram obtidas para o $\mathrm{Pb}$ (II), o Cd(II) e o $\mathrm{Cu}(\mathrm{II})$, respectivamente. $\mathrm{O}$ valor obtido para o chumbo coincide com o obtido pelo método de referência baseado na Espectrofotometria de Absorção Atômica em Forno de Grafite (EAAFG).
\end{abstract}

Square wave anodic stripping voltammetry (SWASV) was applied to the simultaneous determination of trace amounts of toxic metals $\mathrm{Pb}(\mathrm{II}), \mathrm{Cd}(\mathrm{II})$ and $\mathrm{Cu}(\mathrm{II})$ in white poplar (populus) leaves, used as bio indicator and gathered in a chosen area of the city of Lisbon with very high traffic intensity. The leaves were dried and subsequently exposed to an acid digestion microwave process. Square wave parameters were optimized for the voltammetric analysis of the samples. The working electrode consisted of a thin mercury film (TMFE) deposited on the surface of vitreous carbon. The pair $\mathrm{Ag} / \mathrm{AgCl}$ was used as the reference electrode and a Pt wire as the auxiliary electrode. Average concentrations (in $\mathrm{mg}$ of metal $/ \mathrm{kg}$ of dry matter-leaves) of 2.6, 0.18, and 5.0 were obtained for $\mathrm{Pb}(\mathrm{II}), \mathrm{Cd}$ (II) and $\mathrm{Cu}$ (II), respectively. The value for lead coincides with the one obtained by the reference method based on Graphite Furnace Atomic Absorption Spectrophotometry (GFAAS).

Keywords: SWASV, environmental samples, toxic metals, microwave digestion, bio indicator

\section{Introduction}

Among the various environment aggressive agents, toxic metals such as lead $(\mathrm{Pb})$, cadmium $(\mathrm{Cd})$, cobalt $(\mathrm{Co})$, nickel $(\mathrm{Ni})$, mercury $(\mathrm{Hg})$ and copper $(\mathrm{Cu})$ are considered the most prominent. These elements differ from other pollutants since a small concentration increase makes them no longer tolerable, either becoming potentially toxic or contributing to the destruction of the surrounding environment. ${ }^{1-4}$ Since none of these elements is biodegradable, bioaccumulation from air, water, soil or animal nourishment is observed, with latency periods that can last decades. ${ }^{5,6}$

* e-mail: nsilva@deq.isel.ipl.pt
In the particular case of the human body, an excessive presence of any of these elements may result in serious health damages. ${ }^{7-9}$ Lead in excess causes complications in the central nervous system and kidney disturbances. High amounts of cadmium may cause a decrease in kidney's filtration capacity whereas too much cobalt is responsible for heart problems and hypothyroidism. Mercury normally accounts for neuropsychiatric disorders and too much copper leads to hypertension and liver necrosis. Nickel health related effects are skin allergies, lung fibrosis, kidney and cardiovascular system poisoning. ${ }^{10}$

This work aims at contributing to develop and implement a method to analyse and quantify toxic agents in environmental matrixes (tree leaves) and, more 
specifically, to develop and optimize the quantification of lead (and cadmium and copper) in the atmosphere of Lisbon's urban area. Since Lisbon's urban area has a low industrial activity, the main source of lead present in the environment is mainly a result of heavy traffic emissions, which is the case in the studied site.

To meet our purpose, we sought a convenient bio indicator ${ }^{11,12}$ such as tree leaves of a species present all around the area under study. Furthermore, the trees should be of a deciduous species so that new leaves can be obtained each year, assuring therefore the seasonal nature of the study and allowing a future enlargement of the analysis to the whole urban area and its extension to subsequent years. White poplar leaves appeared to be the most appropriate candidate for this end since they meet both criteria. As no other study was found in the literature pertaining to this specific matrix, all the process has been specifically optimized for this end.

SWASV (and other fast techniques) besides showing high sensitivity and selectivity towards toxic metals, ${ }^{13,14}$ uses relatively compact and low price equipment. These characteristics make it a powerful alternative as a field analysis technique. ${ }^{15,16}$ However, SWASV is susceptible to errors arising from the presence of organic matter ${ }^{17,18}$ and therefore, when complex matrixes, ${ }^{19-21}$ either industrial, biological and/or environmental, are under investigation, sample pre treatment is of vital importance because it allows one to minimize the errors caused by organic interferents. ${ }^{22}$ This aspect leads to the need of a method allowing an efficient removal of contaminants prior to analysis. The most convenient procedure involves sample decomposition, which basically consists on the oxidation i.e, mineralization of organic material into carbon dioxide, nitrogen oxides and water ${ }^{22}$ usually by the use of a strong acid. In this process, commonly designated as sample acid digestion, reagents, temperature and digestion time are significant variables that must be optimized for each particular sample since they depend on both the nature and composition of the sample matrix.

\section{Experimental}

\section{Reagents and solutions}

The supporting electrolyte in both test and real solutions was nitric acid $\left(\mathrm{HNO}_{3}\right) 0.1 \mathrm{~mol} \mathrm{~L}^{-1}$, with $\mathrm{pH} \simeq 1$. This solution was prepared from $65 \% \mathrm{HNO}_{3}$ by Merck and ultra pure (Millipore) water with a resistivity greater than $18.2 \mathrm{M} \Omega$.

Concentrated solutions of $\mathrm{Cd}(\mathrm{II}), \mathrm{Pb}(\mathrm{II})$ and $\mathrm{Cu}(\mathrm{II})$ prepared from $1000 \mathrm{mg} \mathrm{L}^{-1}$ standard atomic absorption solutions of $\mathrm{Cd}\left(\mathrm{NO}_{3}\right)_{2}, \mathrm{~Pb}\left(\mathrm{NO}_{3}\right)_{2}$ and $\mathrm{Cu}\left(\mathrm{NO}_{3}\right)_{2}$, from Merck, were used in the SWASV standard addition method, the GFAAS calibration curve method and on the voltammetric parameters optimization assays.

To obtain the mercury film, a $5 \times 10^{-5} \mathrm{~mol} \mathrm{~L}^{-1} \mathrm{Hg}^{2+}$ solution was prepared from a $1000 \mathrm{mg} \mathrm{L}^{-1}$ standard atomic absorption solution of $\mathrm{Hg}\left(\mathrm{NO}_{3}\right)_{2}$, from Merck.

All solutions mentioned above were prepared daily, and glassware was always immersed into chromosulphuric acid, rinsed thoroughly with distilled water and washed with ultra pure water.

\section{Instrumentation}

Square Wave assays were performed using an AUTOLAB PGSTAT 10 potentiostat. This device was computer driven using the AUTOLAB GPES software (version. 4.6). A mercury film deposited on the surface of a $3 \mathrm{~mm}$ diameter vitreous carbon disc, sealed with Teflon was used as the working electrode. The reference electrode was an $\mathrm{Ag} / \mathrm{AgCl}$ electrode saturated with $\mathrm{KCl}\left(3 \mathrm{~mol} \mathrm{~L}^{-1}\right)$. The auxiliary electrode was a spiral platinum wire sealed with glass. The electrochemical cell used consisted on a conventional cell from PAR, adequate for a working volume of about $50 \mathrm{~mL}$ and covered with a Teflon lid.

Atomic Absorption Spectrophotometry assays were performed on a Solaar M5 atomic spectrometer, equipped with flame atomizer, graphite chamber and automated pipette, controlled by a computer through Solaar software (version 9.03).

Microwave sample digestion was performed on a microwave low pressure system, by Microdigest 3.6, equipped with three quartz reaction vessels and an internal Vigreux column.

\section{Procedure}

Samples were collected from five trees (sampling nodes) spotted from the chosen location following a sampling method previously developed ${ }^{23}$ in accordance to internationally accepted procedures ${ }^{24,25}$ to attain a global and homogeneous characterization of the location under study.

Sample pre treatment for analysis consisted of an acid digestion with microwave heating ${ }^{26,27}$ meant to destroy the matrix's organic component. Before digestion, leaves were oven dried at $65^{\circ} \mathrm{C}$ for $96 \mathrm{~h}$, and then grinded until a fine dust was obtained. A mass of $c a .2 \mathrm{~g}$ of this powder, accurately weighed to $\pm 10^{-5} \mathrm{~g}$, was always used in the digestion procedure.

The final residue of this digestion procedure was then dissolved in $20 \mathrm{~mL}$ of a $0.5 \mathrm{~mol} \mathrm{~L}^{-1} \mathrm{HNO}_{3}$ warm solution, filtered and diluted to $100 \mathrm{~mL}$. Quantitative SWASV metal 
determination was performed through the standard addition method, ${ }^{28-30}$ using the experimental conditions described on Table 2. In this procedure, adequate volumes of the appropriate standard metal solutions were added to $25 \mathrm{~mL}$ of the sample solution.

Given the disadvantages of the hanging mercury drop electrode (HMDE), a mercury film electrode was used. ${ }^{31-33}$ The mercury drop has a low surface area to volume ratio, thus the small area reduces the efficiency of the deposition step since it limits the amount of material that can be deposited. The large volume leads to a low metal concentration in the mercury, ${ }^{34}$ which in turn requires longer rest periods between deposition and stripping methods to allow homogenization of the amalgam concentration. In addition, the time required for the metal to diffuse from the drop interior to the solution during the determination step causes broadening of the stripping peaks leading to a loss of sensitivity; another disadvantage of HMDE is that only moderate solution stirring rates can be used to avoid dislodging the drop from the capillary connected to the mercury reservoir.

Thin mercury film electrodes consists of a very thin mercury layer (less than $100 \mathrm{~nm}$ thick) obtained by plating the mercury film from a supporting electrolyte solution with an $\mathrm{Hg}^{2+}$ concentration between $1 \times 10^{-5} \mathrm{~mol} \mathrm{~L}^{-1}$ and $5 \times 10^{-5}$ mol L-1 ${ }^{35,36}$ This electrode offers a large surface area to volume ratio that provides a higher amalgam concentration during the deposition step, resulting in higher plating efficiency. In addition, the diffusion from the bulk of the film to the surface is very fast resulting in superior sensitivity and selectivity. ${ }^{34}$ Plating efficiency and method sensitivity can be enhanced because mercury film electrodes can be used in vigorous convection conditions such as in flow systems, solution stirring and rotating electrodes. ${ }^{37-40}$

Before the mercury film was deposited, the vitreous carbon disc used was polished with $0.02 \mu \mathrm{m}$ grit alumina powder in order to remove any oxidation layer formed due to contact with atmospheric oxygen and/or remaining residues from preceding assays. Abundant washing with ultra pure water followed this step.
In the test solutions the mercury film was deposited directly from $25 \mathrm{~mL}$ of a supporting electrolyte solution with a $\mathrm{Hg}^{2+}$ concentration of $5 \times 10^{-5} \mathrm{~mol} \mathrm{~L}^{-1}$, using $-1.0 \mathrm{~V}$ for $300 \mathrm{~s}$.

For real samples, after dissolving the residue from the digestion procedure in $20 \mathrm{~mL}$ of a $0.5 \mathrm{~mol} \mathrm{~L}^{-1} \mathrm{HNO}_{3}$ warm solution, the final volume of the sample solutions (100 mL), contained $1 \mathrm{~mL}$ of the standard atomic absorption solution of $\mathrm{Hg}\left(\mathrm{NO}_{3}\right)_{2}$ so that the mercury film could be deposited directly from the sample solution.

Since the final sample residue was filtered and diluted to $100 \mathrm{~mL}, 1 \mathrm{~mL}$ of the $1000 \mathrm{mg} \mathrm{L}^{-1}$ standard atomic absorption solution of $\mathrm{Hg}\left(\mathrm{NO}_{3}\right)_{2}$ was needed to obtain the mercury concentration referred above. The total amount of $\mathrm{Hg}^{2+}$ used in this work (for voltammetric parameter optimization, $\mathrm{Pb}$ (II), $\mathrm{Cd}(\mathrm{II})$ and $\mathrm{Cu}(\mathrm{II})$ determination in the samples and blank assays) was therefore estimated to be ca. $15 \mu \mathrm{mol}$.

\section{Results and Discussion}

Microwave digestion has been chosen as it presents several advantages when compared to classical digestion (the conventional sample digestion method), ${ }^{41}$ especially if one seeks a much greater effectiveness in this process. Table 1 summarizes the results for the digestion step optimization.

In the classical process, heat convection occurs from the source to the heated medium, part of the energy being therefore consumed to heat the recipient containing the sample. This usually results in a relatively slow heating process with energy loss and severe limitations in the attainable temperature. Thus, in more complex matrices, compounds such as proteins, fat or silicates suffer incomplete digestion and remain as interferents on the final residue. ${ }^{22}$

In microwave digestion, heating results from the sample's molecular interaction with electromagnetic waves $^{42,43}$ generated heat is dissipated from within the irradiated medium; as radiation flows through the reactor

Table 1. Microwave sample digestion program

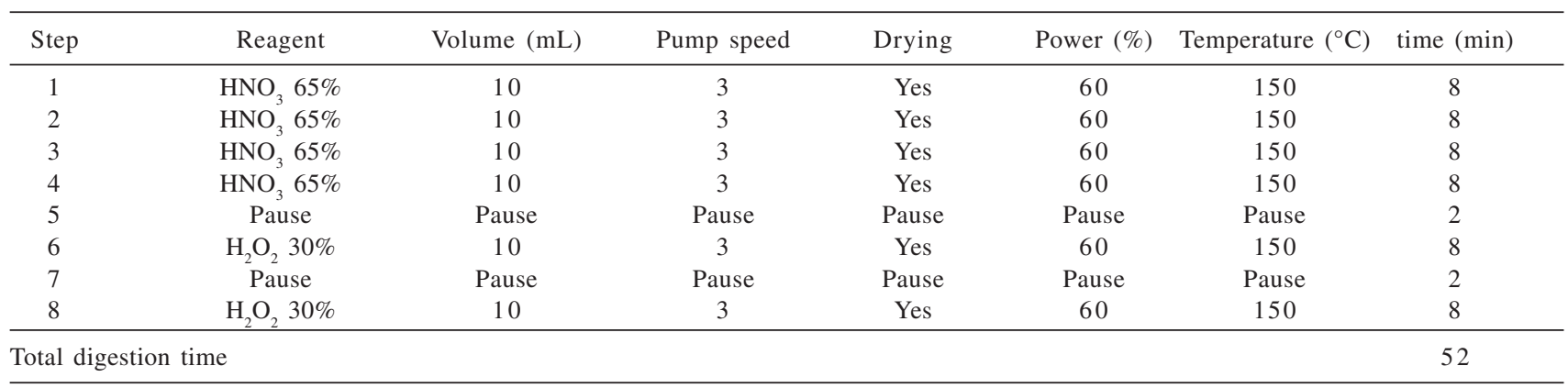


walls without being absorbed, no energy is lost, resulting in significantly faster heating with the possibility of attaining higher digestion temperatures.

The choice of nitric acid as the digestion reagent is due to the fact that being a powerful oxidizer it can decompose or mineralize a large range of samples with a complex nature. ${ }^{44-49}$ In order to destroy any organic matter that might not have been oxidized by nitric acid, a second oxidizer, hydrogen peroxide, was subsequently added. This way, a more effective decomposition of the sample is assured.

To eliminate any insoluble species ensuing from this process, such as calcium fluoride or fluorosilicates, the reaction mixture was dried and the resulting residue dissolved in nitric acid.

The duration of each step was conditioned by the sample's drying time, which in turn depends on the value of the digestion temperature that can reach values as high as $300^{\circ} \mathrm{C}$ on high pressure microwave digestion systems, with the advantage of greatly increasing the oxidizing power of the digestion reagent. In our case a low pressure system was used thus limiting both temperature and the used reagents.

Sensitivity, repeatability and method detection limit were optimized by studying the influence of voltammetric parameters on peak current (I $\mathrm{I}_{\mathrm{p}}$ ) of $\mathrm{Pb}$ (II), $\mathrm{Cd}$ (II) and $\mathrm{Cu}$ (II) in order to achieve the simultaneous determination ${ }^{50,51}$ of all studied metals. The following parameters were studied: deposition potential $\left(\mathrm{E}_{\text {dep }}\right)$, deposition time $\left(\mathrm{t}_{\mathrm{d}}\right)$, square wave frequency (f), square wave impulse amplitude $\left(\mathrm{E}_{\mathrm{sW}}\right)$ and potential step $(\Delta \mathrm{E})$. Figures 1 and 2 illustrate the results for the optimization of $E_{\text {dep }}$ and $t_{d}$, respectively, given their significant influence.

The optimization of the remaining parameters was in all aspects similar to the ones presented in Figure 1 and Figure 2. Based on the experimental results we tried to choose, for each of the remaining parameters, a value

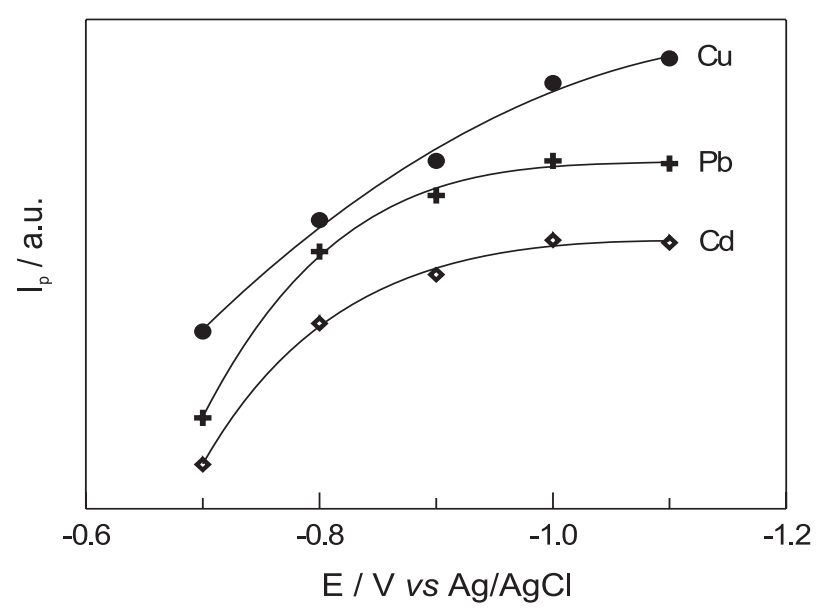

Figure 1. The effect of the deposition potential on cadmium, lead and copper peak currents.

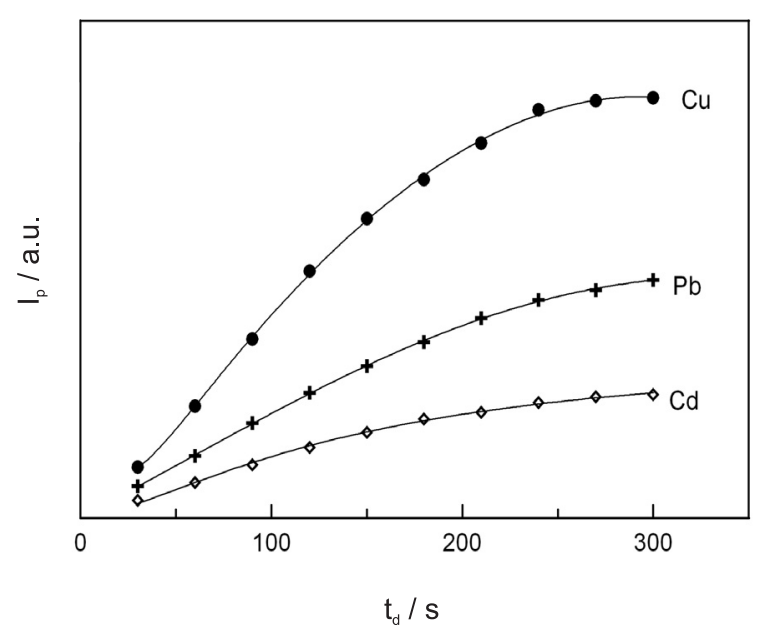

Figure 2. Effect of deposition time on cadmium, lead and copper peak currents.

allowing the simultaneous determination of all metals and the minimization of the background noise (in order to obtain well defined current peaks).

The observation of Figure 1 shows that $\mathrm{I}_{\mathrm{p}}$ increases as $\mathrm{E}_{\text {dep }}$ becomes more negative, stabilizing at about $-1.0 \mathrm{~V}$, as the diffusion control settles in and the limiting current is reached. ${ }^{52}$ Thus, we took $-1.0 \mathrm{~V}$ as the optimum value for $\mathrm{E}_{\text {dep }}$.

The value of $I_{p}$ for the three metals increases with $t_{d e p}$, as can be seen in Figure 2, up to about $225 \mathrm{~s}$. This behaviour can be explained on the grounds of mercury film saturation for higher deposition times, which hinders an increase in $\mathrm{I}_{\mathrm{p}}{ }^{53}$ Therefore, in order to prevent this saturation and to reduce total analysis time, a deposition time of $75 \mathrm{~s}$ was chosen.

Table 2 summarises the optimized values for all voltammetric parameters, the mercury film formation conditions and further experimental conditions.

Voltammograms obtained for several samples showed, almost invariably, a severe reduction of the redissolution peaks for lead and cadmium. In fact, most of the time, no signal could be observed for cadmium as can be seen in the example

Table 2. Optimized experimental conditions for performing SWASV assays

\begin{tabular}{lc}
\hline \multicolumn{1}{c}{ Parameter } & Optimized value \\
\hline Mercury concentration & $5 \times 10^{-5} \mathrm{~mol} \mathrm{~L}^{-1}$ \\
Mercury deposition potential & $-1.0 \mathrm{~V}$ \\
Mercury deposition time & $300 \mathrm{~s}$ \\
Mercury film cleaning potential & $+0.2 \mathrm{~V}$ \\
Mercury film cleaning time after deposition & $120 \mathrm{~s}$ \\
Mercury film cleaning time between measurements & $60 \mathrm{~s}$ \\
Deposition potential of the metals under analysis & $-1.0 \mathrm{~V}$ \\
Deposition time of the metals under analysis & $75 \mathrm{~s}$ \\
Square wave frequency & $125 \mathrm{~Hz}$ \\
Square wave amplitude & $25 \mathrm{mV}$ \\
Potential step & $2 \mathrm{mV}$ \\
Solution deaeration time (with $\mathrm{N}_{2}$ ) & $10 \mathrm{~min}$ \\
Nitric acid concentration & $0.1 \mathrm{~mol} \mathrm{~L}$ \\
Stirring speed & $1000 \mathrm{rpm}$ \\
\hline
\end{tabular}


given in Figure 3. This was due to the need of a current intensity scale adjustment in order to enable the copper peak current reading, given the sample's high content of this metal.

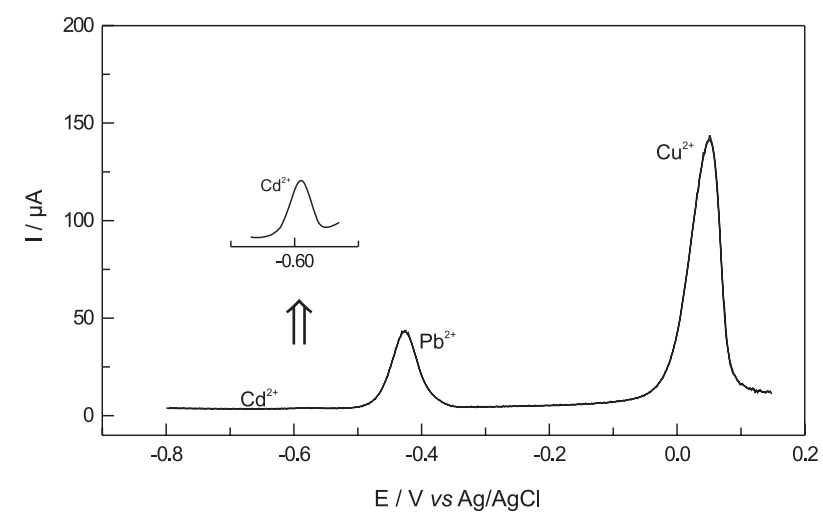

Figure 3. Voltammogram showing the simultaneous determination of $\mathrm{Pb}, \mathrm{Cd}$ and $\mathrm{Cu}$, with cadmium signal hidden due to height of copper peak.

We therefore decided to determine cadmium and lead simultaneously, whereas copper was determined independently, so that the presence or absence of the former two could be properly investigated. In order to detect copper, samples were diluted to $1 / 10$ since the concentration of this metal fell on the saturation zone of the mercury film electrode.

Figures 4 and 5 show the results for the simultaneous determination of cadmium and lead, on one hand and copper, on the other. These figures show examples of voltammograms resulting from the analysis of one of the five sampled trees, as well as the corresponding standard addition calibration lines.

In both figures, the base voltammogram depicted corresponds to the sample signal. The other curves result from the $1^{\text {st }}$ to the $4^{\text {th }}$ addition of standard solution.

The concentration range obtained for the five sampled trees was 2.1 to 3.4 (standard deviation $\mathrm{sd}=0.5$ ) $\mathrm{mg}$ of metal $/ \mathrm{kg}$ of dry matter (leaves) in the case of lead. For cadmium, the determined concentrations were in the range

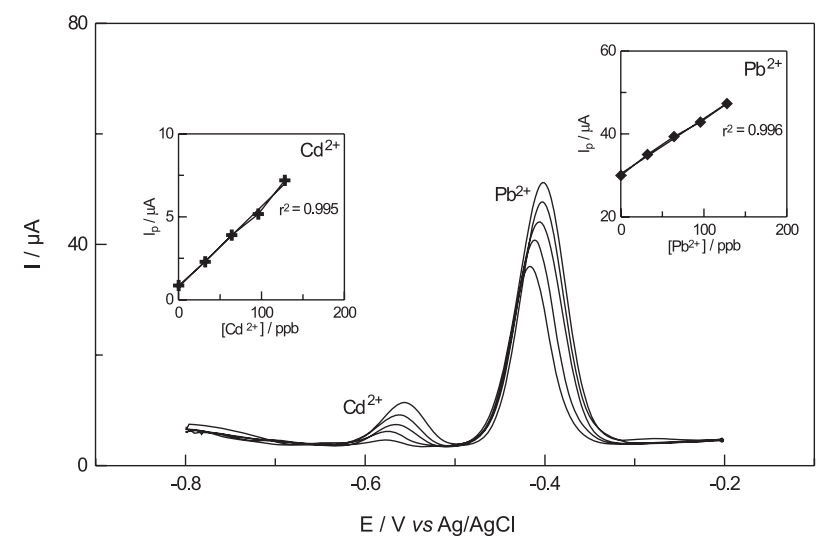

Figure 4. Voltammograms and calibration lines (inserted) obtained in the analysis of cadmium and lead on one of the sampled trees in the Marquês de Pombal square.

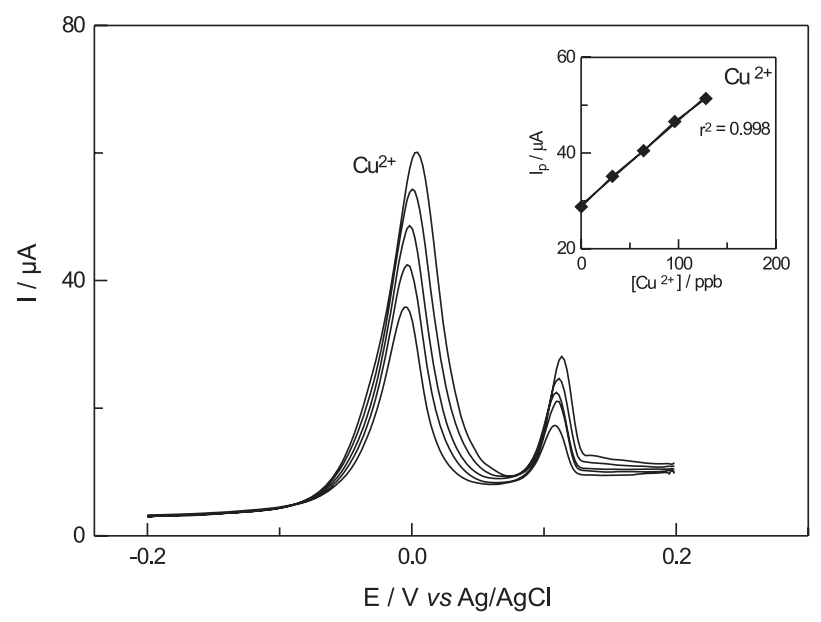

Figure 5. Voltammograms and calibration lines (inserted) obtained in the analysis of copper on one of the sampled trees in the Marquês de Pombal square.

of 0.09 to $0.22(\mathrm{sd}=0.06) \mathrm{mg}$ of metal $/ \mathrm{kg}$ of dry matter.

In the case of copper, the concentration range obtained for the sampled trees was 4.4 to $5.4(\mathrm{sd}=0.4) \mathrm{mg}$ of metal/ $\mathrm{kg}$ of dry matter. The peak observed at a slightly more positive potential than that corresponding to copper redissolution may be due to the formation of an intermetallic compound between copper and some element present only on real samples, since it occurs close to the redissolution peak of copper and it was not detected on test solutions. In addition, the participation of copper in this type of complexation reactions is quite commonly observed giving rise to high formation constants. ${ }^{34,54}$

The detected intermetallic behaviour, on the other hand, is characteristic of this type of compounds, namely, base line instability, non linearity between redissolution current peak and copper concentration and peak potential shift (usually positive, as observed in this work). ${ }^{55,56}$

As mentioned above, samples were collected from five trees in a central area of the city of Lisbon (Marquês de Pombal). The assays performed on each tree's sample consisted in measuring the metals' current intensity directly in the sample, and after each of four additions of a standard solution containing adequate concentrations of cadmium and lead, or copper. The current intensity values considered for each standard addition resulted from the average of five replicates. Table 3 shows the results obtained in the determination of cadmium, lead and copper in one of the five sampled trees, where the precision of the method is evaluated by means of the standard deviation calculation..$^{57}$ The assays performed in the rest of the trees resulted in similar precision.

The resulting coefficient of variation (x 100) is about $1.6 \%$ for the three metals showing the good overall precision of the method. Given the complex nature of the used samples and the repeatability estimate, the method 
Table 3. Precision of the method exemplified with the results obtained in one of the five sampled trees

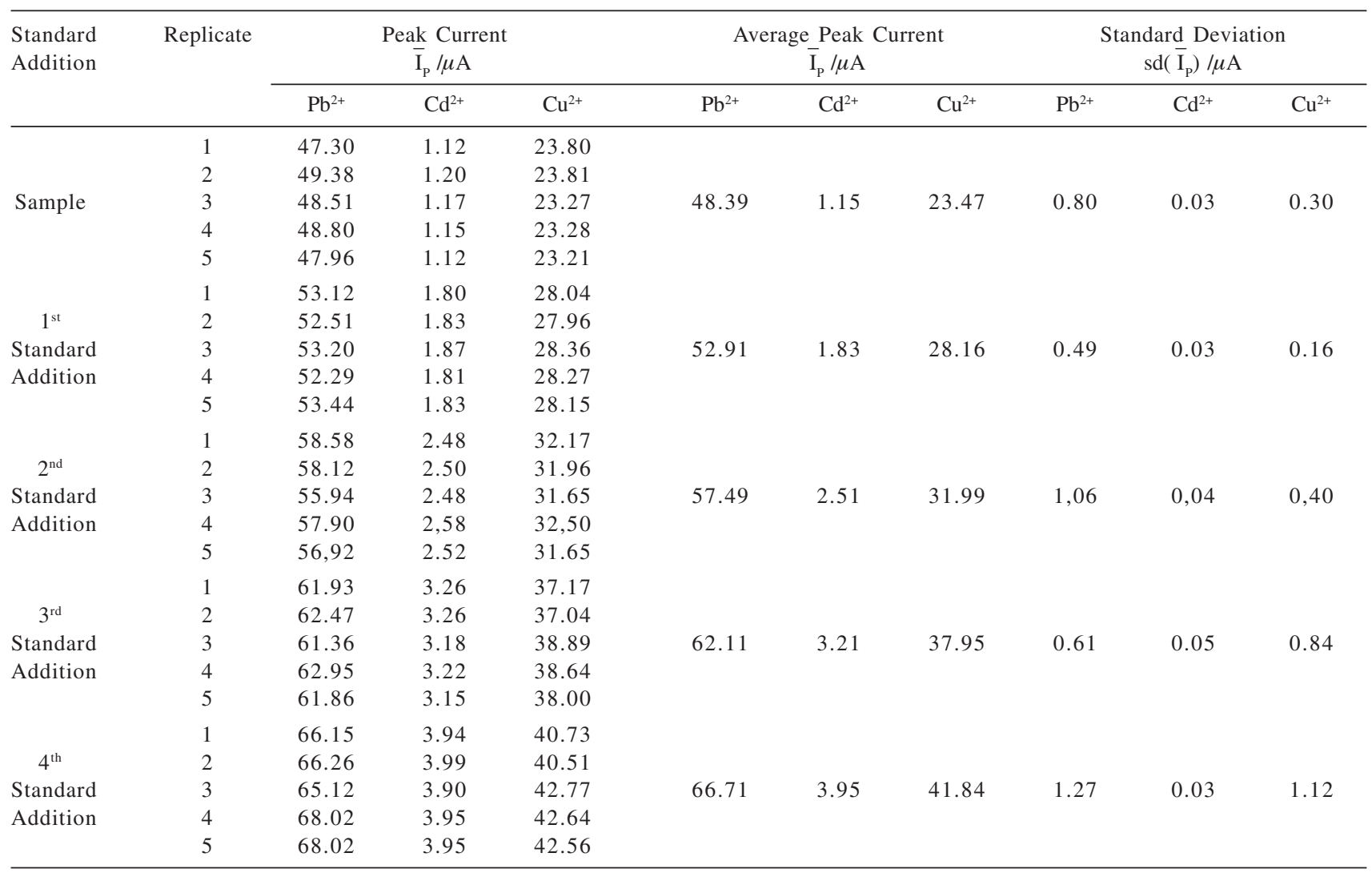

shows a significant precision that is partially due to the digestion procedure performed to the samples as a pre treatment before analysis, since it minimizes errors arising from the presence of any residual organic matter.

The result obtained by SWASV, i.e., $2.6 \mathrm{mg}$ of $\mathrm{Pb} / \mathrm{kg}$ of dry matter (leaves), coincides with that obtained with GFAAS ${ }^{58,30}$ i.e., $2.6 \mathrm{mg}$ of $\mathrm{Pb} / \mathrm{kg}$ of dry matter (leaves) using lead as reference element. This observation opens excellent perspectives towards the validation of the herein proposed method, although a more complete validation, including results from cadmium and copper, must also be considered in the near future. A comparison with GFAAS is presented only for lead because initially the main objective of this work was to determine the total amount of accumulated atmospheric lead.

The comparison of our values with background values was not possible given the total absence of data about background values for these metals in the studied area.

\section{Conclusions}

The combination of SWASV with the procedure developed for organic matter decomposition (acid microwave digestion) was clearly successful. This aspect is particularly relevant since SWASV, being extremely sensitive to the presence of organic matter on the solution under analysis, requires therefore, as mentioned above, an adequate pre treatment of complex matrix samples in order to allow the removal of contaminants prior to analysis.

Results obtained in this work allow us to conclude, in general terms, that the proposed method can be used for the simultaneous determination of traces of toxic metals in samples of the chosen type.

This statement is partly supported by the observed behaviour of metals on real samples, namely the existing linearity between concentration and peak current and because typical values for the redissolution peak potential of each metal were obtained. The excellent measurements repeatability shows that the developed technique is highly precise, especially considering that we are dealing with real, complex, samples.

As for metals detected on white poplar leaves, their origin is most likely atmospheric although an unknown amount may originate from the soil where these trees are planted, because of bioaccumulation. ${ }^{59-61}$ Given the results obtained with white poplar leaves, we foresee the possibility of using this bio indicator to monitor the variation of the amount of atmospheric pollutants every year. ${ }^{62}$ 
Monitoring heavy metal concentration in urban areas originating from traffic emissions is essential as a means to assert the quality of the environment, identify the factors that favour accumulation of pollutants in certain areas, determine the residence time of these species on the chosen matrix and possibly correlate it to health disorders such as allergies, asthma, etc.

This process ${ }^{63-65}$ appears to be a valid alternative to other, more classical analytical procedures, such as airborne particles collection using glass, quartz or teflon filters to retain the particles ${ }^{65-67}$ or stainless steel canisters lined with fused silica ${ }^{68}$ In future applications the procedure developed in this work may be used to monitorize metallic elements in environmental samples for long periods.

Hence, the method and results presented in this work embody significant environmental relevance.

\section{References}

1. Brett, C. M. A.; Garcia, M. B. Q.; Lima, J. L. F. C.; Portugaliae Electrochim. Acta 1997, 15, 351.

2. Palmieri, R. M.; La Pera, L.; Di Bella, G.; Dugo, G.; Chemosphere 2005, 59, 1161.

3. Usero, J.; Morillo, J.; Gracia, I.; Chemosphere 2005, 59, 1175.

4. Kools, S. A .E.; van Roovert, M.; van Gestel, C. A. M.; van Straalen, N. M.; Soil Biol. Biochem. 2005, 37, 1303.

5. Riba, I.; Blasco, J.; Jiménez-Tenorio, N.; Del Valls, T. A.; Chemosphere 2005, 58, 659.

6. Amaral, M. C. R.; Rebelo, M. de F.; Torres, J. P. M.; Pfeiffer, W. C.; Mar. Environ. Res. 2005, 59, 277.

7. Williams, R. J. P.; Fraústo da Silva, J.J.R.; The Natural Selection of The Chemical Elements, Clarendon Press Oxford: Oxford, 1996.

8. Davydova, S.; Microchem. J. 2005, 79, 133.

9. Mercier, G.; Duchesne, J.; Carles-Gibergues, A.; Environ. Pollut. 2002, 118, 285.

10. Denkhaus, E.; Salnikow, K.; Critic. Rev. in Oncol.-Hem. 2002, 42, 35 .

11. Pignata, M. L.; GudiHo, G. L.; Wannaz, E. D.; Plá, R. R.; González, C. M.; Carreras, H. A.; Orellana, L.; Environ. Pollut. 2002, 120, 59.

12. MacFarlane, G. R.; Booth, D. J.; Brown, K. R.; Aquat. Toxicol. 2000, 50, 153.

13. Buffle, J.; Tercier-Waeber, M.L.; Trends Anal. Chem. 2005, 24, 172.

14. Farghalya, O. A.; Ghandourb, M. A.; Environ. Res. 2005, 97, 229.

15. PalmSens: Handheld instrument for electrochemical sensors, http://www.palmsens.com, accessed in November 2003.

16. Palchetti, I.; Laschi, S.; Mascini, M.; Anal. Chim. Acta 2005, $530,61$.

17. Hoyer, B.; Jensen, N.; Electrochem. Commun. 2003, 5, 257.

18. Hoyer, B.; Jensen, N.; Electrochem. Commun. 2003, 5, 759.
19. Kim, H-J.; Yun, K-S.; Yoon, E.; Kwak, J.; Electrochim. Acta 2004, 50, 205.

20. Gazy, A. A. K.; Talanta 2004, 62, 575.

21. Brainina, Kh. Z.; Stozhko, N.Y.; Belysheva, G. M.; Inzhevatova, O. V.; Kolyadina, L. I.; Cremisini, C.; Galletti, M.; Anal. Chim. Acta 2004, 514, 227.

22. Hoenig, M.; Talanta 2001, 54, 1021.

23. Silva, N. A. F.; MSc. Dissertation, Faculdade de Ciências da Universidade de Lisboa, Portugal, 2003.

24. United Nations Economic Commission for Europe Convention on Long-Range Transboundary Air Pollution, Manual on methods and criteria for harmonized sampling, assessment, monitoring and analysis of the effects of air pollution on forests, 1994.

25. European Environment Agency, Air Pollution in Europe 1977, 1998.

26. Agazzi, A.; Pirola, C.; Microchem. J. 2000, 67, 337.

27. Sastre, J.; Sahuquilho, A.; Vidal, M.; Rauret. G.; Anal. Chim. Acta 2002, 462, 59.

28. Silva, P. R. M.; El khakani, M. A.; Chaker, M.; Dufresne, A.; Courchesne, F.; Sens. Actuators, B 2001, 76, 250.

29. Locatelli, C.; Torsi, G.; J. Electroanal. Chem. 2001, 509, 80.

30. Locatelli, C.; Torsi, G.; Microchem. J. 2004, 78, 175.

31. El-Hady, D. A.; Abdel-Hamid, M. I.; Seliem, M. M.; Andrisano, V.; El-Maali, N. A.; J. Pharm. Biomed. Anal. 2004, 34, 879.

32. Farghaly, O. A.; Microchem. J. 2003, 75, 119.

33. Farghaly, O. A.; Talanta 2004, 63, 497.

34. Wang, J.; Stripping Analysis-Principles, Instrumentation and Application, VCH Publishers: Deerfield Beach, FL, 1985.

35. Monterroso, S. C. C.; Carapuça, H. M.; Simão, J. E. J.; Duarte, A. C.; Anal. Chim. Acta 2004, 503, 203.

36. Carapuça, H. M.; Monterroso, S. C. C.; Rocha, L. S.; Duarte, A. C.; Talanta 2004, 64, 566.

37. Lam, M. T.; Chakrabarti, C. L.; Cheng, J.; Pavski, V.; Electroanalysis 1997, 9, 1018.

38. Dalangin, R. R.; Gunasingham, H.; Anal. Chim. Acta 1994, $291,81$.

39. Murimboh, J.; Lam, M. T.; Hasan, N. M.; Chakrabarti, C. L.; Anal. Chim. Acta 2000, 423, 115.

40. Suteerapataranon, S.; Jakmunee, J.; Vaneesorn, Y.; Grudpan, K.; Talanta 2002, 58, 1235.

41. Stoeppler, M.; Sampling and Sample Preparation, SpringerVerlag: Berlin, 1997.

42. Larhed M.; Hallberg, A.; Drug Discovery Today 2001, 6, 406.

43. Lidstrom, P.; Tierney, J.; Wathey, B.; Westman, J.; Tetrahedron 2001, 57, 9225.

44. Li, D-M.; Zhang L-X.; Wang, X-H.; Liu, L-B.; Anal. Chim. Acta 2003, 482, 129.

45. Wang, J.; Nakazato, T.; Sakanishi, K.; Yamada, O.; Tao, H.; Saito, I.; Anal. Chim. Acta 2004, 514, 115.

46. Niemelä, M.; Perämäki, P.; Piispanen, J.; Poikolainen, J.; Anal. Chim. Acta 2004, 521, 137. 
47. Kuo, C-Y.; Wu, C-H.; Lo, S-L.; J. Hazard. Mater. B 2005, 120, 249.

48. Saavedra, Y.; González, A.; Fernández P.; Blanco, J.; Spectrochim. Acta, Part B 2004, 59, 533.

49. Sandroni, V.; Smith, C. M. M.; Talanta 2003, 60, 715.

50. Mamani, M. C. V.; Aleixo, L. M.; Abreu, M. F.; Rath, S.; J. Pharm. Biomed. Anal. 2005, 37, 709.

51. Munoz, R. A. A.; Angnes, L.; Microchem. J. 2004, 77, 157.

52. Fischer, E.; Berg, C. M. G. V. D.; Anal. Chim. Acta 1999, 385, 273.

53. Neto, M. M. P. M.; Rocha, M. M. G. S.; Campos, I. M. N.; Portugaliae Electrochim. Acta 2001, 19, 57.

54. Brett, C. M. A.; Garcia, M. B. Q.; Lima, J. L. F. C.; Anal. Chim. Acta 1997, 339, 167.

55. Staden, J. F. V.; Matoetoe, M. C.; Anal. Chim. Acta 2000, 411, 201.

56. Ben-Bassat, A. H. I.; Azrad, A.; Electrochim. Acta 1978, 23, 63.

57. Massart, D.L.; Vandeginste, B.G.M.; Deming, S.N.; Michotte, Y.; Kaufman, L.; Chemometrics: A Textbook, Elsevier: Amsterdam, 1988.

58. Matos, M. J.; Silva, N. A. F.; Arruda, T. M.; Silva, H. F.; Borges, V. M.; Lopes, I. S.; Leitão, R. E.; abstracts of the $3^{\text {rd }}$
European Meeting on Environmental Chemistry, Geneva, Switzerland, 2002.

59. Viard, B.; Pihan, F.; Promeyrat, S.; Pihan, J-C.; Chemosphere 2004, 55, 1349.

60. An, Y-J.; Kim, Y-M.; Kwon, T-I.; Jeong, S-W.; Sci. Total Environ. 2004, 326, 85.

61. Chojnacka, K.; Chojnacki, A.; Górecka, H.; Górecki, H.; Sci. Total Environ. 2005, 337, 175.

62. MacFarlane, G. R.; Pulkownik, A.; Burchett, M. D.; Environ. Pollut. 2003, 123, 139.

63. Komarnicki, G. J. K.; Environ. Pollut. 2005, 136, 47.

64. Yusuf, A. A.; Arowolo, T. A.; Bamgbose, O.; Food Chem. Toxicol. 2003, 41, 375.

65. Lammel, G.; Bruggemann, E.; Gnauk, T.; Muller, K.; Neususs, C.; Rohrl, A.; J. Aerosol Sci. 2003, 34, 1.

66. Tsapakis, M.; Stephanou, E. G.; Atmos. Environ. 2003, 37, 4935.

67. Braziewicz, J.; Kownacka, L.; Majewska, U.; Korman, A.; Atmos. Environ. 2004, 38, 1989.

68. Wu, C-H.; Feng, C-T.; Lo, Y-S.; Lin, T-Y.; Lo, J-G.; Chemosphere 2004, 56, 71.

Received: December 6, 2004 Published on the web: October 11, 2005 